\title{
Comparison of two methods for sialometry: weighing and volume techniques
}

\begin{abstract}
- Murillo Brunheroto Sacon General dentist, Department of Stomatology, Oral Medicine, School of Dentistry, University of São Paulo, São Paulo, SP, Brazil • Camilla Vieira Esteves Master in Science and Phd Student, Department of Stomatology, Oral Medicine, School of Dentistry, University of São Paulo, São Paulo, SP, Brazil • Giovanna Piacenza Florezi Master in Science Student, Department of Stomatology, Oral Medicine, School of Dentistry, University of São Paulo, São Paulo, SP, Brazil - Andressa Ferreira Gonçalves Dentistry student, Department of Stomatology, Oral Medicine, School of Dentistry, University of São Paulo, São Paulo, SP, Brazil • Cláudio Mendes Pannuti Associate professor of the discipline of periodontology, Department of Stomatology, Periodontology, School of Dentistry, University of São Paulo, São Paulo, SP, Brazil - Celso Augusto Lemos-Júnior Associate professor of the discipline of Oral Medicine, Department of Stomatology, Oral Medicine, School of Dentistry, University of São Paulo, São Paulo, SP, Brazil
\end{abstract}

ABSTRACT | The composition of saliva is essential for the oral cavity homeostasis, therefore, the decrease in salivary flow leads to consequences, such as an increase of dental caries, dry mouth and lips, dysgeusia, dysphagia, gingivitis, halitosis, mastication problems, oral mucositis, oral pharyngeal candidiasis, sleeping and speaking difficulties and traumatic oral lesions. The objective of this study was to evaluate the efficacy of the sialometry technique by weighing in comparison to the sialometry technique by volume. Fifty patients without previous complaint of xerostomia and/or hyposalivation were selected at the Oral Medicine Clinic, Dentistry School, University of São Paulo, Brazil. All samples were collected between $9 \mathrm{am}$ and $10 \mathrm{am}$ and the whole saliva was collect stimulated and unstimulated. Six cotton rolls were prepared, divided into three pairs and placed in different universal dispensers of a random brand, they were weighed in a previously calibrated analytical balance (FA-2104N CELTAC). The sialometry test was performed in three steps: unstimulated salivary flow, salivary flow with stimulation of $1 \%$ citric acid solution and stimulation of $1 \%$ citric acid solution every 30 seconds. The results of the weighing method were compared to the standard method. There was no significant statistical difference between the two types of collection and $100 \%$ of the participants expressed their preference for the weighing method.

DESCRIPTORS | Saliva; Salivary Elimination; Salivary Glands; Salivation.

RESUMO | Comparação de dois métodos de sialometria: técnicas de pesagem e volume • A composição da saliva é essencial para homeostase da cavidade oral. Assim sendo, a diminuição do fluxo salivar pode levar ao aumento da incidência de cáries, boca seca, alteração no paladar, alteração na deglutição, gengivite, halitose, problemas mastigatórios, mucosites, candidíases, problemas no sono, fala e lesões orais traumáticas. O objetivo deste estudo foi avaliar a técnica de sialometria por peso em comparação com a técnica tradicional de sialometria por volume, com coleta de saliva estimulada e não estimulada. Cinquenta pacientes com ou sem queixa prévia de xerostomia ou hipossalivação foram selecionados na clínica de Estomatologia da Faculdade de Odontologia da Universidade de São Paulo, Brasil. Todas as coletas foram realizadas entre 9 e 10 horas da manhã. Seis rolos de algodão foram separados e divididos em três pares e colocados em três diferentes coletores plásticos universais, sendo cada conjunto pesado previamente em balança analítica calibrada. O teste de sialometria foi realizado em três etapas: fluxo salivar sem estimulação; estimulado com 1\% de ácido cítrico em aplicação única; e estimulado com aplicação de $1 \%$ de ácido cítrico a cada 30 segundos até completar 2 minutos. Esses resultados por peso foram comparados com o método de sialometria por volume tradicional. Não houve diferença estatística observada entre os dois métodos de coleta e $100 \%$ dos pacientes preferiram a coleta realizada com roletes de algodão.

DESCRITORES | Saliva; Eliminação Salivar; Glândulas Salivares; Salivação.

CORRESPONDING AUTHOR | • Celso Augusto Lemos-Júnior Department of Stomatology, School of Dentistry, University of Sao Paulo • Av. Professor Lineu Prestes, 2227 São Paulo, SP Brazil • 05508-000 E-mail: calemosj@usp.br

- Received Nov. 17, 2016 • Accepted July 12, 2017

- Dol http://dx.doi.org/10.11606/issn.2357-8041.clrd.2017.122887 


\section{INTRODUCTION}

The salivary glands are part of the large collection of glands within the endocrine system of human beings, they are responsible for maintaining the balance of the stomatognathic system through saliva production. ${ }^{1}$

Saliva is essential to the homeostasis of the oral mucosa and some substances found in whole saliva help to maintain the integrity of oral tissues. Mucin is the main product of the submandibular gland, sublingual gland and minor glands, it is responsible for providing lubrication and protection for the mucous membranes. ${ }^{2}$ Statherin is responsible for maintaining high levels of calcium available, thus improving the teeth remineralization and histatins that have antimicrobial proprieties..$^{3-5}$

Therefore, the decrease in salivary flow can cause consequences, such as an increase of dental caries, dry mouth and lips, dysgeusia, dysphagia, gingivitis, halitosis, mastication problems, mucositis, oralpharyngeal candidiasis, sleeping and speaking difficulties and traumatic oral lesions. ${ }^{6,7}$

With the increase in life expectancy, there are more complaints about the dry mouth sensation, xerostomia, from the geriatric population due to the increased use of medications, and systemic diseases. ${ }^{8,9}$ There are studies that sought to prove that salivary flow decreases with aging, and this decrease is known to have a remarkable effect on the life quality of older adults. ${ }^{9}$ Hyposalivation is manifested by a reduction in salivary flow and included in the etiology are Sjögren Syndrome, uncontrolled diabetes mellitus, HIV, lupus erythematosus, rheumatoid arthritis, Parkinson's disease, head and neck radiation therapy and eating disorders..$^{10}$ According to Ship et al. ${ }^{11}$, the inhibition of acetylcholine binding to muscarinic receptors on the acinar cells is responsible for the development of an anticholinergic effect, leading to an impact on the quality and quantity of salivary output.
These malfunctions must be accurately diagnosed, and this has led to the development of easy and precise methods of diagnosis, providing fast results so an effective therapy can be implemented, and the prognosis of the malfunction can be favorable.

Sialometry is the most common method to diagnose salivary flow malfunctions. Hyposalivation, for example, is diagnosed based on the salivary flow measured by sialometry and the result must be under $0.1 \mathrm{~mL} / \mathrm{min}$ of non-stimulated saliva. ${ }^{1,12,13}$

The objective of this study was to evaluate the efficacy of sialometry technique by weighing in comparison to the sialometry technique by volume. In addition, we also evaluated the acceptance of the method by the patient, ease of using the method and comparison of the results of both weighing and volume techniques.

\section{METHODS}

Fifty patients were selected at the Oral Medicine Clinic, Dentistry School, University of São Paulo, Brazil. This study was approved by Research Ethics Committee of the institution. All samples were collected between $9 \mathrm{am}$ and $10 \mathrm{am}$, the participants were instructed not to eat, drink or brush their teeth at least 2 hours before the collection. The age of the participants ranged from 20 to 50 years. The inclusion criteria were that subjects should not present complaints of xerostomia or have used any medication that could interfere in salivary flow or of xerostomic potential such as: antihypertensive and psychotropics. All volunteers agreed to participate in this study, they signed an Informed Consent Form and answered a questionnaire regarding their habits, general health, xerostomia and medication.

Six cotton rolls were prepared, divided into three pairs and placed in different universal dispensers of a random brand. The whole set was 
weighed in a previously calibrated analytical balance (FA-2104N CELTAC) with a variation of less than $0.001 \mathrm{~g}$ (Figure 1). Whole saliva was collected by spit method, a funnel was linked into a graduated lab cylinder (Figure 2). All samples were centrifugated to obtain the supernatant saliva that can be used for analyses.

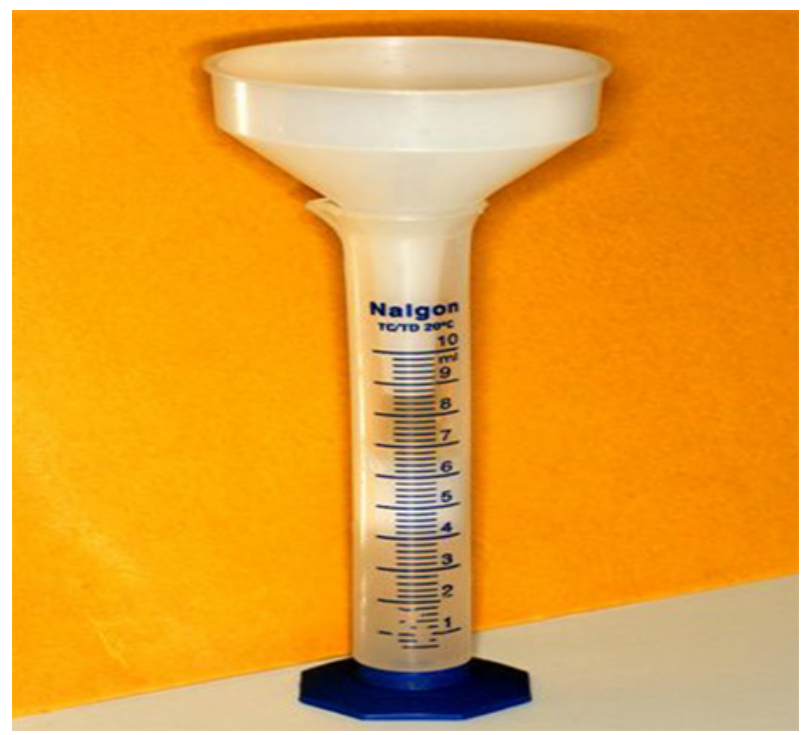

Figure 1 | A funnel was inserted into a graduated lab cylinder to collect saliva by volume

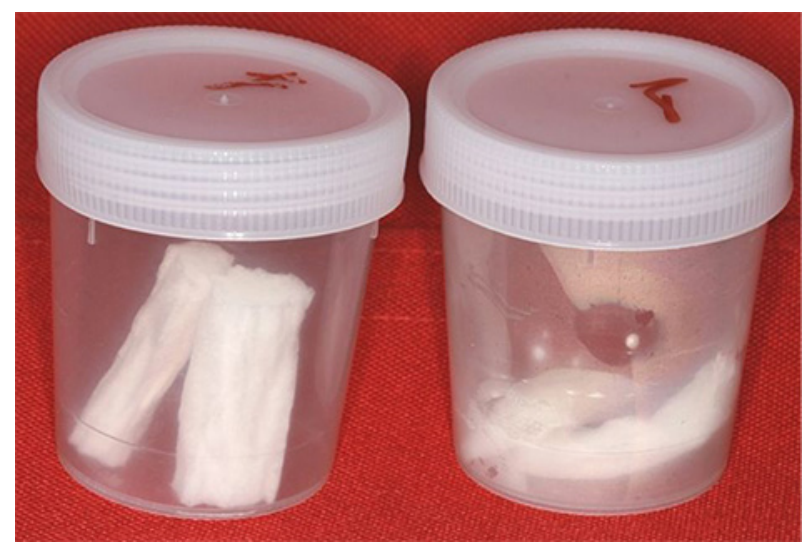

Figure 2 | Cotton rolls were prepared, divided into three pairs and placed in different universal dispensers of a random brand

The sialometry test was performed in three steps. First, the patients were instructed to swallow all saliva present in their oral cavity, then, two previously weighed cotton rolls were placed on each side of the floor of the mouth. The subject could not swallow for two minutes, the rolls were then removed and put into the universal dispenser be weighed again. Five minutes after this procedure we applied the standard method, which consisted of the patient spitting saliva into the lab cylinder for five minutes, without stimulation (P1 test). The second step was performed ten minutes later.

On the second step the salivary flow was stimulated with $1 \%$ citric acid solution. Two drops of solution were poured onto the dorsum of the tongue and the patient was asked to swallow the saliva immediately. The standard sialometry test was performed again as previously detailed (P2 test). The third step was performed ten minutes later.

The third step ( $\mathrm{P}_{3}$ test) consisted of hyperstimulation of salivary production. Two drops of citric acid were poured onto the dorsum of the tongue and the patient was asked to swallow the saliva immediately. Subsequently, the last two cotton rolls were placed in the mouth of the volunteer, and for two minutes we applied two drops of citric acid in the same location, resulting in a total of eight drops. The set was weighed and the difference in weight was converted into millimeters per minute $(\mathrm{mL} / \mathrm{min})$. The standard collection method was performed with stimulation every 60 seconds for five minutes. All data obtained were converted into $\mathrm{mL} / \mathrm{min}$.

Table 1 | Differences between methods (cotton rolls $\times$ standard test)

\begin{tabular}{|c|c|c|c|}
\hline & & Cotton test & $\begin{array}{l}\text { Standard } \\
\text { Sialometry }\end{array}$ \\
\hline \multicolumn{2}{|c|}{$\begin{array}{l}\text { Duration of each } \\
\text { phase }\end{array}$} & 2 minutes & 5 minutes \\
\hline \multirow{3}{*}{ Procedure } & P1 & $\begin{array}{l}\text { Salivary flow without } \\
\text { stimulation }\end{array}$ & $\begin{array}{c}\text { Salivary flow } \\
\text { without stimulation }\end{array}$ \\
\hline & P2 & $\begin{array}{l}\text { Previous stimulation } \\
\text { with } 1 \% \text { citric acid }\end{array}$ & $\begin{array}{c}\text { Previous } \\
\text { stimulation with 1\% } \\
\text { citric acid }\end{array}$ \\
\hline & P3 & $\begin{array}{l}\text { Stimulation with } 1 \% \\
\text { citric acid every } 30 \\
\text { seconds }\end{array}$ & $\begin{array}{c}\text { Stimulation with } 1 \% \\
\text { citric acid every } 60 \\
\text { seconds }\end{array}$ \\
\hline
\end{tabular}




\section{RESULTS}

The mean age of the volunteers was 26 years old; We analyzed 28 men and 22 women. Regarding their habits, 10 participants reported smoking, 40 reported driking socially and 10 reported no such habits. The statistical analyses were performed on paired samples, using the t-test.

There was no statistically significant difference between the two types of collection, without stimulation ( $\mathrm{p}=0.84)$, with stimulation (2 drops before collection), $(\mathrm{p}=0.42)$ and with continuous stimulation ( $\mathrm{p}=0.51)$ (Table 2). All participants
(100\%) expressed preference for the weighing method. Table 3 shows the general results obtained after each collection (results in $\mathrm{mL} / \mathrm{min}$ ).

Table 2 | Statistical test t for paired samples

\begin{tabular}{|c|c|c|c|}
\hline $\begin{array}{c}\text { Nollection } \\
\text { No }\end{array}$ & Standard & With Cotton & p-value \\
\hline $\begin{array}{c}\text { With } \\
\text { Stimulation } \\
(2 \text { drops })\end{array}$ & $1.13 \pm 0.51 \pm 0.41$ & $0.80 \pm 0.40$ & 0.84 \\
\hline $\begin{array}{c}\text { Continuous } \\
\text { stimulation }\end{array}$ & $1.78 \pm 0.69$ & $1.83 \pm 0.58$ & 0.51 \\
\hline
\end{tabular}

Table 3 | General results obtained after each collection (results in $\mathrm{mL} / \mathrm{min}$ )

\begin{tabular}{|c|c|c|c|c|c|c|c|c|c|}
\hline & \multicolumn{2}{|c|}{$\begin{array}{c}\mathrm{P} 1 \\
\text { No Stimulation }\end{array}$} & \multirow[b]{2}{*}{ Dif \% } & \multicolumn{2}{|c|}{$\begin{array}{c}\text { P2 } \\
\text { With Stimulation (2 drops) }\end{array}$} & \multirow[b]{2}{*}{ Dif \% } & \multicolumn{2}{|c|}{$\begin{array}{c}\text { P3 } \\
\text { Continuous stimulation }\end{array}$} & \multirow[b]{2}{*}{ Dif \% } \\
\hline & Standard & Cotton & & Standard & Cotton & & Standard & Cotton & \\
\hline Test 01 & 0.800 & 1.025 & 28.1 & 0.880 & 0.960 & 9.1 & 0.880 & 1.910 & 117.0 \\
\hline Test 02 & 0.320 & 0.430 & 34.4 & 0.280 & 0.680 & 142.9 & 0.280 & 1.690 & 503.6 \\
\hline Test 03 & 0.600 & 0.520 & -13.3 & 0.680 & 1.220 & 79.4 & 1.080 & 2.270 & 110.2 \\
\hline Test 04 & 0.300 & 0.500 & 66.7 & 0.600 & 1.500 & 150.0 & 1.320 & 1.700 & 28.8 \\
\hline Test 05 & 0.600 & 0.250 & -58.3 & 0.660 & 0.590 & -10.6 & 1.340 & 1.530 & 14.2 \\
\hline Test 06 & 0.400 & 0.200 & -50.0 & 0.500 & 0.300 & -40.0 & 0.800 & 0.780 & -2.5 \\
\hline Test 07 & 0.520 & 0.900 & 73.1 & 0.860 & 0.990 & 15.1 & 1.900 & 2.000 & 5.3 \\
\hline Test 08 & 1.000 & 1.000 & 0.0 & 1.200 & 0.990 & -17.5 & 1.400 & 1.230 & -12.1 \\
\hline Test 09 & 0.800 & 0.789 & -1.4 & 1.000 & 1.043 & 4.3 & 1.600 & 1.925 & 20.3 \\
\hline Test 10 & 0.400 & 0.390 & -2.5 & 0.400 & 0.520 & 30.0 & 1.400 & 1.350 & -3.6 \\
\hline Test 11 & 0.600 & 0.905 & 50.8 & 1.000 & 1.132 & 13.2 & 1.400 & 1.980 & 41.4 \\
\hline Test 12 & 0.600 & 0.829 & 38.2 & 0.800 & 1.238 & 54.8 & 1.600 & 1.806 & 12.9 \\
\hline Test 14 & 1.000 & 0.760 & -24.0 & 1.200 & 0.491 & -59.1 & 1.800 & 0.927 & -48.5 \\
\hline Test 15 & 1.000 & 0.681 & -31.9 & 1.400 & 1.345 & -3.9 & 2.000 & 2.617 & 30.9 \\
\hline Test 16 & 0.800 & 0.758 & -5.3 & 1.000 & 1.100 & 10.0 & 1.400 & 1.767 & 26.2 \\
\hline Test 17 & 1.600 & 0.163 & -89.8 & 1.800 & 1.147 & -36.3 & 2.400 & 1.919 & -20.0 \\
\hline Test 18 & 0.500 & 0.498 & -0.4 & 0.640 & 0.597 & -6.7 & 1.380 & 1.350 & -2.2 \\
\hline Test 19 & 1.200 & 0.952 & -20.7 & 1.200 & 1.518 & 26.5 & 1.600 & 2.182 & 36.4 \\
\hline Test 20 & 0.600 & 0.802 & 33.7 & 0.800 & 1.523 & 90.4 & 1.200 & 2.113 & 76.1 \\
\hline Test 21 & 0.600 & 0.785 & 30.8 & 0.940 & 1.021 & 8.6 & 1.740 & 1.729 & -0.6 \\
\hline Test 22 & 0.700 & 0.885 & 26.4 & 0.840 & 0.911 & 8.5 & 1.540 & 1.494 & -3.0 \\
\hline Test 23 & 0.900 & 0.808 & -10.2 & 1.040 & 1.042 & 0.2 & 1.620 & 1.620 & 0.0 \\
\hline
\end{tabular}

continues... 
Table 3 | Continuation

\begin{tabular}{|c|c|c|c|c|c|c|c|c|c|}
\hline & \multicolumn{2}{|c|}{$\begin{array}{c}\text { P1 } \\
\text { No Stimulation }\end{array}$} & \multirow[b]{2}{*}{ Dif \% } & \multicolumn{2}{|c|}{$\begin{array}{c}\text { P2 } \\
\text { With Stimulation (2 drops) }\end{array}$} & \multirow[b]{2}{*}{ Dif \% } & \multicolumn{2}{|c|}{$\begin{array}{c}\text { P3 } \\
\text { Continuous stimulation }\end{array}$} & \multirow[b]{2}{*}{ Dif \% } \\
\hline & Standard & Cotton & & Standard & Cotton & & Standard & Cotton & \\
\hline Test 24 & 1.000 & 0.959 & -4.1 & 1.400 & 1.540 & 10.0 & 1.800 & 2.205 & 22.5 \\
\hline Test 25 & 0.800 & 0.770 & -3.8 & 1.000 & 1.100 & 10.0 & 1.600 & 1.899 & 18.7 \\
\hline Test 26 & 0.900 & 1.040 & 15.6 & 0.860 & 0.890 & 3.5 & 1.500 & 1.190 & -20.7 \\
\hline Test 27 & 0.149 & 0.152 & 2.4 & 0.395 & 0.353 & -10.6 & 0.963 & 0.746 & -22.5 \\
\hline Test 28 & 0.050 & 0.042 & -15.4 & 0.153 & 0.128 & -16.3 & 0.500 & 0.459 & -8.2 \\
\hline Test 29 & 0.012 & 0.013 & 4.2 & 0.126 & 0.100 & -20.6 & 0.412 & 0.399 & -3.2 \\
\hline Test 30 & 0.527 & 0.857 & 62.6 & 0.931 & 1.112 & 19.4 & 1.880 & 1.987 & 5.7 \\
\hline Test 31 & 1.500 & 1.668 & 11.2 & 1.500 & 2.201 & 46.7 & 3.000 & 2.664 & -11.2 \\
\hline Test 32 & 1.000 & 0.926 & -7.4 & 1.500 & 1.747 & 16.5 & 2.500 & 2.116 & -15.4 \\
\hline Test 33 & 0.500 & 1.320 & 164.0 & 1.000 & 1.726 & 72.6 & 3.000 & 2.309 & -23.0 \\
\hline Test 34 & 1.000 & 0.649 & -35.1 & 1.500 & 1.835 & 22.3 & 2.500 & 2.240 & -10.4 \\
\hline Test 35 & 0.250 & 0.283 & 13.0 & 1.500 & 1.367 & -8.9 & 1.500 & 2.054 & 37.0 \\
\hline Test 36 & 0.500 & 0.728 & 45.5 & 1.500 & 1.305 & -13.0 & 2.500 & 2.339 & -6.4 \\
\hline Test 37 & 1.300 & 1.079 & -17.0 & 1.500 & 1.543 & 2.9 & 2.500 & 2.203 & -11.9 \\
\hline Test 38 & 1.250 & 1.154 & -7.6 & 2.000 & 1.301 & -35.0 & 2.250 & 1.860 & -17.3 \\
\hline Test 39 & 1.000 & 0.926 & -7.5 & 1.500 & 1.183 & -21.2 & 2.300 & 1.700 & -26.1 \\
\hline Test 40 & 1.500 & 1.418 & -5.5 & 1.500 & 1.183 & -21.2 & 3.000 & 2.230 & -25.7 \\
\hline Test 41 & 1.200 & 0.950 & -20.8 & 1.400 & 0.629 & -55.1 & 1.800 & 0.951 & -47.1 \\
\hline Test 42 & 1.500 & 1.579 & 5.3 & 1.700 & 1.734 & 2.0 & 2.250 & 2.156 & -4.2 \\
\hline Test 43 & 1.200 & 1.407 & 17.3 & 1.600 & 1.683 & 5.2 & 2.200 & 2.188 & -0.6 \\
\hline Test 44 & 1.500 & 1.354 & -9.7 & 2.500 & 2.393 & -4.3 & 3.000 & 2.742 & -8.6 \\
\hline Test 45 & 0.900 & 0.761 & -15.5 & 2.000 & 2.049 & 2.5 & 2.500 & 2.353 & -5.9 \\
\hline Test 46 & 1.300 & 1.241 & -4.5 & 2.000 & 1.995 & -0.2 & 2.200 & 2.122 & -3.5 \\
\hline Test 47 & 0.900 & 0.900 & -0.1 & 1.500 & 1.325 & -11.7 & 2.500 & 2.459 & -1.6 \\
\hline Test 48 & 0.459 & 0.489 & 6.5 & 1.200 & 1.028 & -14.3 & 2.800 & 3.005 & 7.3 \\
\hline Test 49 & 1.250 & 1.390 & 11.2 & 1.600 & 1.785 & 11.6 & 2.000 & 2.256 & 12.8 \\
\hline Test 50 & 0.400 & 0.356 & -11.0 & 0.600 & 0.564 & -6.0 & 0.900 & 1.045 & 16.1 \\
\hline Mean & 3.969 & 3.924 & & 5.569 & 5.766 & & 8.753 & 8.977 & \\
\hline Diference \% & \multicolumn{2}{|c|}{-1.1} & & \multicolumn{2}{|c|}{3.5} & & \multicolumn{2}{|c|}{2.5} & \\
\hline
\end{tabular}

\section{DISCUSSION}

The participants of this study were selected by their age and health condition, the inclusion criteria were being in the same age group; having no complaints or symptoms of xerostomia or hyposalivation; or take any medications that could interfere in salivary flow; or have any basis diseases. Thus, the sample was homogenous, and the method itself could be analyzed with no external interferences. This study can be performed with different age groups, medication users, eating disorders or syndromes that affect the salivary flow. 
This study was developed so every step of the technique could be observed, with no interference of the material in the final results, previous studies were affected by this. For example, a study conducted in The South Australian Dental Longitudinal Study, in which the containers were not weighed. Despite presenting differences in weigh, the saliva samples derived from different batches, which means the method must be followed precisely, so the results can be achieved, as were the results of this study.

Poll E. M et al. ${ }^{13}$ performed a study using four commercially available saliva collection devices: Drool collected in a sterile specimen container; Salimetrics ${ }^{\circledR}$ Oral Swab (SOS); (C) Salivette $\AA$ (Sarstedt) Cotton and Synthetic; Greiner Bio-One and Saliva Collection System $®$ (GBO SCS $®$ ). The results showed significant differences on analytic level depending on the collection method. There were also significant differences on the salivary flow rates depending on the saliva collection method. This study used the same conditions and inclusion criteria as our study, however the focus was on saliva collection devices to quantify proteins present in saliva and to provide levels for C-reactive protein (CRP), myoglobin, and immunoglobulin $\mathrm{E}$ (IgE) on the saliva of healthy individuals.

Michishige et al. ${ }^{14}$ compared three methods (suction method, spitting method and swab method) to collect saliva, in this study the samples were collected from $2 \mathrm{pm}$ to $3 \mathrm{pm}$, however the interval of collection was the same in both studies. The results were different, since the Michishige study was influenced by the circadian rhythm, which did not happen in our research.

There was a discussion regarding the accuracy of the method, as the collection by volume presented incoherencies due to the bubbles formed in the tube of saliva, interfering in the final measurement, however, the results showed no differences. The method proved to be easy on patients with masticatory difficulties resulting from aging or tooth loss. We used $1 \%$ citric acid instead of presoftened polyvinyl acetate gum or paraffin wax, thus, there were no difficulties or discomforts caused by chewing.

Previous studies ${ }^{1-7,8}$ showed that the differences in the final results were due to the different methods, age, exclusion and inclusion criteria, however this study demonstrated that the method did not interfere in the final results when collecting saliva to measure salivary level. Nevertheless, other factors, such as the design of the studies may have an influence, reinforcing the idea that what influences the results is not the method, but the sample studied.

\section{CONCLUSION}

The conclusion of this study is that the method did not influence the final measurement results.

\section{ACKNOWLEDGEMENTS}

The authors would like to thank the financial support from FAPESP 2010/10906-9 (Fundação de Amparo à Pesquisa do Estado de São Paulo) to Undergraduate Research (Iniciação Científica).

\section{REFERENCES}

1. Johansson AK, Jorkjend L, Marthinussen MC, Johansson A. A comparison of two clinical methods for measuring saliva in patients with Sjögren's syndrome. Acta Odontol Scand. 2012;70(3):251-4. doi: 10.3109/00016357.2011.640285.

2. Pramanik R, Osailan SM, Challacombe SJ, Urquhart D, Proctor GB. Protein and mucin retention on oral mucosal surfaces in dry mouth patients. Eur J Oral Sci. 2010;118(3):245-53. doi: 10.1111/j.1600-0722.2010.00728.x.

3. Challacombe SJ, Percival RS, Marsh PD. Age-related changes in immunoglobulin isotypes in whole and parotid saliva and serum in healthy individuals. Oral Microbiol Immunol. 1995;10(4): 202-7. doi: 10.1111/j.1399-302X.1995.tboo143.x

4. Turner RJ. Mechanisms of fluid secretion by salivary glands. Ann N Y Acad Sci. 1993;694:24-35. doi: 10.1111/j.17496632.1993.tb18339.x. 
5. Rudney JD. Does variability in salivary protein concentrations influence oral microbial ecology and oral health? Crit Rev Oral Biol Med. 1995;6(4):343-67. doi: 10.1177/10454411950060040501.

6. Alamoudi N, Farsi N, Faris J, Masoud I, Merdad K, Meisha D. Salivary characteristics of children and its relation to oral microorganism and lip mucosa dryness. J Clin Pediatr Dent. 2004;28(3):239-48. doi: 10.17796/ jcpd.28.3.h24774507006l55o.

7. Schein OD, Hochberg MC, Muñoz B, Tielsch JM, Bandeen-Roche K, Provost T, et al. Dry eye and dry mouth in the elderly: a population-based assessment. Arch Intern Med. 1999;159(12):1359-63. doi: 10.1001/ archinte.159.12.1359.

8. Koseki M, Maki Y, Matsukubo T, Ohashi Y, Tsubota K. Salivary flow and its relationship to oral signs and symptoms in patients with dry eyes. Oral Dis. 2004;10(2):75-80. doi: 10.1111/j.1354-523X.2003.00987.x.

9. Smith CH, Boland B, Daureeawoo Y, Donaldson E, Small $\mathrm{K}$, Tuomainen J. Effect of aging on stimulated salivary flow in adults. J Am Geriatr Soc. 2013;61(5):805-8. doi: 10.1111/ jgs.12219.

10. Delli K, Spijkervet FK, Kroese FG, Bootsma H, Vissink A. Xerostomia. Monogr Oral Sci. 2014;24:109-25. doi: 10.1159/000358792.

11. Ship JA, Pillemer SR, Baum BJ. Xerostomia and the geriatric patient. J Am Geriatr Soc. 2002;50(3):535-43. doi: 10.1046/j.1532-5415.2002.50123.x.

12. Löfgren CD, Wickström C, Sonesson M, Lagunas PT, Christersson C. A systematic review of methods to diagnose oral dryness and salivary gland function. BMC Oral Health. 2012;12:29. doi: 10.1186/1472-6831-12-29.

13. Poll EM, Kreitschmann-Andermahr I, Langejuergen Y, Stanzel S, Gilsbach JM, Gressner A, et al. Saliva collection method affects predictability of serum cortisol. Clin Chim Acta. 2007;382(1-2):15-9. doi: 10.1016/j.cca.2007.03.009.

14. Michishige F, Kanno K, Yoshinaga S, Hinode D, Takehisa Y, Yasuoka S. Effect of saliva collection method on the concentration of protein components in saliva. J Med Invest. 2006;53(1-2):140-6. doi: 10.2152/jmi.53.140. 